\title{
Pemberian Asam Valproat pada Induk Tikus Bunting Menghambat Sintesis Insulin pada Sel Otak Anak Tikus
}

\author{
Komariah, ${ }^{1}$ Bambang Kiranadi, ${ }^{2}$ Adi Winanto, ${ }^{2}$ Wasmen Manalu, ${ }^{2}$ Ekowati Handharyani ${ }^{2}$ \\ ${ }^{1}$ Fakultas Kedokteran Gigi Universitas Trisakti Bagian Biomedik, ${ }^{2}$ Departemen Anatomi, Fisiologi, dan Farmakologi \\ Fakultas Kedokteran Hewan Institut Pertanian Bogor
}

\begin{abstract}
Abstrak
Asam valproatmemengaruhi aktivitas histone deacetylase yang berperan dalam ekspresi gen selama organogenesis. Insulin berperan dalam proliferasi dan diferensiasi sel-sel saraf dentate gyrus hipokampus. Penelitian ini bertujuan mempelajari pengaruh pemaparan asam valproat pada induk bunting terhadap ekspresi gen insulin pada dentate gyrus. Penelitian dilakukan di UPHL IPB pada bulan Mei 2015 hingga Desember 2016 dengan 84 ekor anak tikus yang dilahirkan oleh induk tikus kontrol yang diberi asam valproat $250 \mathrm{mg}$ pada umur kebuntingan 10, 13, dan 16 hari digunakan untuk pengamatan kadar glukosa, insulin, DNA, RNA, dan rasio RNA/DNA serta pengamatan mikroskopis otak. Pengamatan dilakukan selang waktu empat minggu, dimulai dari umur 4 sampai 32 minggu. Anak tikus yang dilahirkan oleh induk tikus yang diberi asam valproat selama kebuntingan mempunyai kadar glukosa otak yang lebih tinggi $(\mathrm{p}<0,01)$ dan insulin yang lebih rendah $(\mathrm{p}<0,05)$. Selama periode pertumbuhan, anak tikus yang dilahirkan oleh induk tikus yang diberi asam valproat mengalami peningkatan kadar glukosa dan penurunan kadar insulin $(\mathrm{p}<0.05)$. Pengamatan mikroskopis sel-sel dentate gyrus menunjukkan degenerasi sel dan tidak terlihat reaksi imunoreaktif terhadap insulin, namun terjadi penurunan konsentrasi DNA, RNA, serta rasio RNA/DNA $(p<0,05)$. Pemberian asam valproat pada induk tikus pada umur kebuntingan 10, 13, dan 16 hari memengaruhi organogenesis otak anak tikus sehingga menyebabkan kerusakan sel-sel saraf penghasil insulin otak yang ditunjukkan oleh penurunan sekresi dan kadar insulin. [MKB. 2017;49(3):156-64]
\end{abstract}

Kata kunci: Asam valproat, dentate gyrus, insulin, organogenesis

\section{Valproic Acid Administration in Pregnant Rats Inhibits Insulin Synthesis n in Brain Cells of the Offsprings}

\begin{abstract}
Valproic acid affects the activity of histone deacetylase which eventually affects gene expression during organogenesis. Insulin plays a role in regulating the proliferation and differentiation of the dentate gyrus. This experiment was designed to study the effects of valproic acid administration on the expression of insulin gene in the dentate gyrus of pregnant rats. This study was carried out at the Laboratory Animal Management Unit (UPHL) of Bogor Agricultural University from May 2015 to December 2016, with eighty four newborn rats from control rats and VA-administered rats at the age of 10,13, and 16 days of pregnancy. The measurements were done for glucose, insulin, DNA, and RNA concentrations in dentate gyrus and to observe the microscopic condition of the brain at the ages of 4 to 32 weeks with 4 weeks interval. Rats born form mothers administered by $250 \mathrm{mg}$ valproic acid during pregnancy had higher glucose concentrations $(\mathrm{p}<0.01)$ and lower insulin concentrations $(\mathrm{p}<0.05)$ in the dentate gyrus. During the post-natal growth phase, rats born from mothers administered with valproic acid had increased glucose concentrations and decreased insulin concentrations $(\mathrm{p}<0.05)$. Microscopic observations of the dentate gyrus showed degeneration of nerve cells with no immunoreaction to insulin was seen in dentate gyrus cells. However, the concentrations of DNA, RNA, and the ratio of RNA/DNA in the dentate gyrus cells decreased $(\mathrm{p}<0.05)$. The administration of valproic acid to pregnant rats at the age of 10,13 , and 16 days of pregnancy destructs brain organogenesis of the offsprings which eventually disturbs insulin production in the dentate gyrus indicated by decreased insulin secretion and concentrations. [MKB. 2017;49(3):156-64]
\end{abstract}

Key words: Dentate gyrus, insulin, organogenesis, valproic acid

Korespondensi: Komariah, S.Si., M.Biomed, Fakultas Kedokteran Gigi Universitas Trisakti, Bagian Biomedik, Jalan Kyai Tapa, Kampus B, Grogol, Jakarta Barat, E-mail: akomariah67@gmail.com 


\section{Pendahuluan}

Otak merupakan organ yang sensitif terhadap insulin yang dikuatkan oleh teridentifikasinya reseptor insulin dan jalur tranduksi signal di beberapa daerah dalam otak. ${ }^{1}$ Insulin berperan memediasi beberapa efek fisiologis yang penting pada organ otak, seperti pensignalan proliferasi dan diferensiasi sel saraf di hipotalamus dan hipokampus, khususnya di bagian dentate gyrus hipokampus. ${ }^{2}$ Hipokampus merupakan bagian otak yang mensintesis dan menghasilkan insulin tingkat tinggi yang berperan dalam memori dan pembelajaran. ${ }^{3}$ Gangguan sintesis insulin dalam otak dapat menganggu fungsi neuron dan sinaptogenesis yang akan berkembang pada penyakit neurodegeneratif. ${ }^{4}$

Studi terbaru menunjukkan bahwa obatobat pengurang rasa sakit akibat peradangan dan neuropatik, seperti obat antiepilepsi (OAE) dapat berperan sebagai bahan teratogenik. Penggunaan asam valproat banyak disarankan oleh para ahli neurologi Amerika sebagai pilihan pertama atau kedua untuk terapi migrain. ${ }^{5}$ Migrain merupakan gangguan neurologis kronik yang dapat memengaruhi $12 \%$ populasi manusia dengan populasi terbanyak pada wanita. ${ }^{6}$

Asam valproat merupakan salah satu obat antiepilepsi yang juga memengaruhi modifikasi histon selama proses proliferasi dan diferensiasi sel dengan jalan memengaruhi aktivitas enzim histone deacetylase (HDAC). Asam valproat secara langsung bekerja dengan menghambat aktivitas enzim HDAC yang dapat menyebabkan hiperasetilasi histon melalui pengikatan pusat katalisis pada HDAC. ${ }^{7}$

Pemaparan induk terhadap asam valproat melalui penggunaan asam valproat oleh induk pada masa atau umur kehamilan tertentu dapat mengganggu ekspresi gen-gen yang berperan dalam perkembangan pankreas dan otak pada fetus. Kerusakan sel beta pankreas terjadi pada saat fetus mengalami perkembangan di rahim, tepatnya pada awal terjadinya organogenesis, bersamaan dengan berkembangnya neuronal tube sebagai awal perkembangan sel saraf. ${ }^{8}$ Pada periode ini terjadi juga ekspresi gen yang tumpang tindih secara luas, seperti ekspresi gen $P d x 1$, gen $N k x 6.1,{ }^{9}$ dan ekspresi gen $N g n 3,{ }^{10}$ dapat meyebabkan disfungsi dan kematian sel beta pankreas, bersamaan dengan sel-sel saraf penghasil insulin. ${ }^{8}$ Tujuan penelitian ini ialah mempelajari kemampuan asam valproat dalam memengaruhi proses organogenesis pada fetus tikus dan dampaknya pada perkembangan selsel saraf dentate gyrus hipokampus otak yang berperan dalam sintesis insulin.

\section{Metode}

Dalam penelitian ini dipergunakan 30 ekor tikus putih $S$. dawley betina dengan bobot badan 200-250 g serta berumur 3-4 bulan. Sebelum dikawinkan, induk tikus itu disuntik $P G F 2 \alpha$ (Noroprost $\AA$ ) untuk penyerentakan berahi. Pada masa kebuntingan, induk tikus dikelompokkan berdasar perlakuan. Kelompok pertama adalah tikus yang tidak diberikan asam valproat sebagai kontrol (K0). Kelompok perlakuan diberikan asam valproat (Depakote ${ }^{\circledR}$ diproduksi oleh Abbott Laboratories) dengan dosis 250 mg pada umur kebuntingan hari ke10 bertepatan dengan ekspresi gen $P d x 1$ (K1), pemberian pada umur kebuntingan hari ke-13 bertepatan dengan ekspresi gen $N k x 6.1(\mathrm{~K} 2)$, dan pemberian pada umur kebuntingan hari ke16 saat terekspresinya gen $\mathrm{Ngn} 3(\mathrm{~K} 3)$. Setelah kelahiran, anak tikus dipisahkan dari induknya pada usia 4 minggu. Terdapat 84 ekor anak tikus dipelihara dan dikelompokkan berdasar atas perlakuan pada induk (Tabel 1).

Selama pemeliharaan, anak tikus percobaan diberikan pakan standar dan air minum yang tersedia secara ad libitum. Pengambilan sampel dilakukan setiap 4 minggu mulai minggu ke-4 hingga minggu ke-32. Rentang jarak setiap 4 minggu pengamatan dilakukan berdasar atas penelitian pendahuluan. Pada kurun waktu kurang dari 4 minggu perkembangan selsel penghasil insulin di pankreas maupun di otak secara mikroskopik belum memberikan perubahan yang signifikan. Penelitian dan penanganan tikus percobaan dilakukan mengikuti kode etik hewan yang dikeluarkan oleh Komisi Etik Hewan, Institut Pertanian Bogor dengan nomor registrasi SKEH 031/KEH/ SKE/IV/2015.

Kadar glukosa otak tikus diukur menggunakan metode glucose kits based/GOD-PAP (Human Co Ltd., Jerman). Kadar insulin dalam jaringan otak ditentukan dengan metode SDS-PAGE menggunakan $\mathrm{BCA}^{\mathrm{TM}}$ Protein Assay Kit(Thermo Scientific, USA). Kadar DNA diukur menggunakan metode genomic DNA mini kit (tissue) dan total RNA mini kit (tissue) (PT Genetika Science Indonesia).

Pembuatan preparat histologi, pemotretan, dan pembacaan dilakukan di Laboratorium Patologi dan Laboratorium Histologi, Fakultas Kedokteran Hewan, Institut Pertanian Bogor. Preparat diwarnai menggunakan hematoksilin- 
Komariah: Pemberian Asam Valproat pada Induk Tikus Bunting Menghambat Sintesis Insulin pada Sel Otak Anak Tikus

Tabel 1 Kelompok Anak Tikus yang Dilahirkan oleh Induk Tikus yang tidak Diberi Asam Valproat Sebagai Kontrol dan Induk Tikus yang Diberi $250 \mathrm{mg}$ Asam Valproat pada Umur Kebuntingan Hari ke-10, 13, dan 16

\begin{tabular}{|c|c|c|c|c|c|c|c|c|c|}
\hline \multirow{2}{*}{ Kelompok } & \multirow{2}{*}{ Kelompok Induk } & \multicolumn{7}{|c|}{ Umur Anak (Minggu) } & \multirow{2}{*}{$\begin{array}{c}\text { Jumlah } \\
\text { Tikus } \\
\text { F1 }\end{array}$} \\
\hline & & 4 & 8 & 12 & 16 & 20 & 24 & 32 & \\
\hline K0 & $\begin{array}{l}\text { Kontrol, tidak diberi asam } \\
\text { valproat }\end{array}$ & 3 & 3 & 3 & 3 & 3 & 3 & 3 & 21 \\
\hline K1 & $\begin{array}{l}\text { Diberi asam valproat } 250 \mathrm{mg} \\
\text { pada umur kebuntingan hari } \\
\text { ke-10 }\end{array}$ & 3 & 3 & 3 & 3 & 3 & 3 & 3 & 21 \\
\hline $\mathrm{K} 2$ & $\begin{array}{l}\text { Diberi asam valproat } 250 \mathrm{mg} \\
\text { pada umur kebuntingan hari } \\
\text { ke-13 }\end{array}$ & 3 & 3 & 3 & 3 & 3 & 3 & 3 & 21 \\
\hline K3 & $\begin{array}{l}\text { Diberi asam valproat } 250 \mathrm{mg} \\
\text { pada umur kebuntingan hari } \\
\text { ke-16 }\end{array}$ & 3 & 3 & 3 & 3 & 3 & 3 & 3 & 21 \\
\hline
\end{tabular}

eosin (HE) dan imunohistokimia terhadap insulin. Pengamatan jaringan otak dengan pewarnaan imunohistokimia dan HE dilakukan dengan menggunakan mikroskop indomikro CX31 Olympus.

Data kuantitatif tersebut dianalisis statistik menggunakan SPSS versi 23. Hasil dinyatakan sebagai mean \pm SD. Perbedaan signifikansi kadar glukosa, DNA, RNA, dan rasio RNA/DNA jaringan otak dianalisis menggunakan uji one-way analysis of variance (ANOVA). Jika hasil penelitian bersifat signifikan dilakukan uji post-hoc Bonferroni. Kadar insulin otak dianalisis menggunakan uji Kruskal-Wallis yang dilanjutkan dengan uji posthoc Mann-Whitney jika ditemukan perbedaan nyata $(\mathrm{p}<0,05) .{ }^{11}$

\section{Hasil}

Pemberian asam valproat saat masa kebuntingan induk tikus memengaruhi kadar glukosa otak anak tikus rata-rata $(p<0,05)$. Jika dibanding dengan anak tikus dari induk yang tidak diberikan asam valproat, sedangkan kadar glukosa selama periode pertumbuhan berbeda nyata rata-rata $(\mathrm{p}<0,01)$ dari minggu ke-4 hingga ke-32.

Pada kelompok anak tikus dengan kontrol K0, peningkatan kadar glukosa otak terjadi pada minggu ke-32, sedangkan pada kelompok anak tikus dari induk tikus yang diberi asam valproat pada kebuntingan hari ke-10 (K1), peningkatan kadar glukosa otak terjadi pada minggu ke-24. Pada kelompok anak tikus dari induk tikus yang diberi asam valproat pada kebuntingan 13 hari (K2), peningkatan kadar glukosa dalam jaringan otak terjadi pada minggu ke-16. Pada anak tikus yang dari induk yang diberi asam valproat pada kebuntingan 16 hari (K3), peningkatan kadar glukosa terjadi pada minggu ke-24. Kadar glukosa rata-rata dalam jaringan otak anak tikus percobaan disajikan pada Gambar 1.

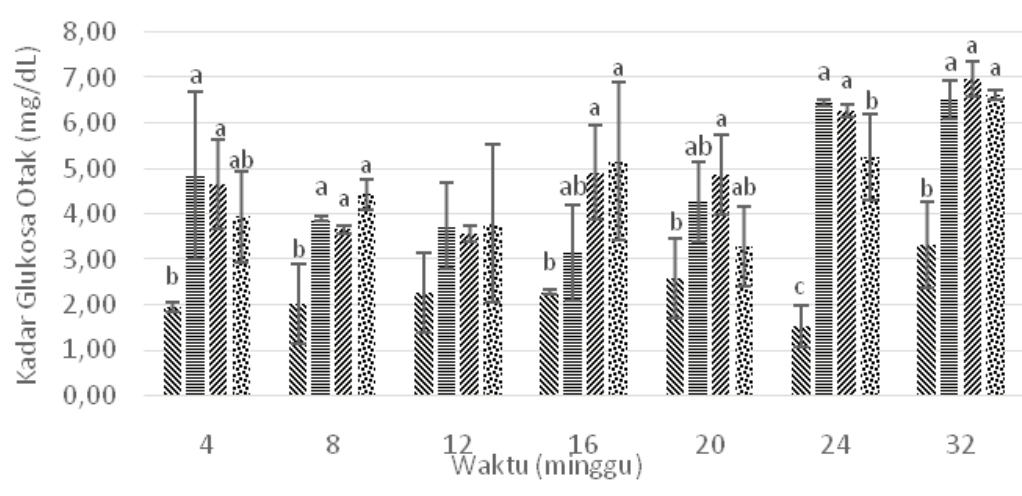

Gambar 1 Kadar Glukosa Otak Anak Tikus yang Dilahirkan oleh Kelompok Induk K0, Induk Tikus Kelompok K1, K2, dan Induk K3 
Komariah: Pemberian Asam Valproat pada Induk Tikus Bunting Menghambat Sintesis Insulin pada Sel Otak Anak Tikus

Tabel 2 Hasil Konsentrasi DNA, RNA, dan Rasio RNA/DNA Rata-rata pada Jaringan Otak Anak Tikus yang Dilahirkan oleh Induk Kontrol (K0) dan Induk yang Diberi Asam Valproat pada Umur Kebuntingan 10 Hari (K1), 13 Hari (K2), dan 16 Hari (K3)

\begin{tabular}{|c|c|c|c|c|c|c|}
\hline \multirow{2}{*}{ Parameter } & \multirow{2}{*}{$\begin{array}{c}\text { Waktu } \\
(\mathrm{minggu}) \\
(\mathrm{n}=3)\end{array}$} & \multicolumn{4}{|c|}{ Kelompok } & \multirow{2}{*}{$\begin{array}{c}\text { Nilai } \\
\mathbf{p}\end{array}$} \\
\hline & & К0 & K1 & K2 & K3 & \\
\hline \multirow{8}{*}{$\begin{array}{l}\text { Konsentrasi } \\
\text { DNA }(\mu \mathrm{g} / \\
\text { mg) }\end{array}$} & 4 & $9,219 \pm 0,07^{\mathrm{a}}$ & $8,29 \pm 0,09^{b}$ & $8,643 \pm 0,05^{b}$ & $8,352 \pm 0,09^{b}$ & 0,018 \\
\hline & 8 & $8,713 \pm 0,51^{\mathrm{a}}$ & $8,48 \pm 0,09^{a b}$ & $8,158 \pm 0,05^{b}$ & $8,349 \pm 0,13^{\mathrm{ab}}$ & 0,017 \\
\hline & 12 & $8,689 \pm 0,41^{a}$ & $8,42 \pm 0,16^{\mathrm{ab}}$ & $8,016 \pm 0,12^{b}$ & $8,673 \pm 0,12^{a}$ & 0,024 \\
\hline & 16 & $8,214 \pm 0,14$ & $8,09 \pm 0,18$ & $8,011 \pm 0,01$ & $8,313 \pm 0,12$ & 0,186 \\
\hline & 20 & $9,449 \pm 1,32^{\mathrm{a}}$ & $7,92 \pm 0,37^{\mathrm{b}}$ & $8,091 \pm 0,01^{\mathrm{ab}}$ & $8,234 \pm 0,12^{\mathrm{ab}}$ & 0,010 \\
\hline & 24 & $8,226 \pm 0,13^{a}$ & $8,19 \pm 0,10^{\mathrm{b}}$ & $7,988 \pm 0,10^{\mathrm{b}}$ & $8,640 \pm 0,14^{\mathrm{b}}$ & 0,023 \\
\hline & 32 & $9,314 \pm 1,11$ & $7,76 \pm 0,99$ & $8,215 \pm 0,05$ & $8,162 \pm 0,01$ & 0,187 \\
\hline & 4 & $18,37 \pm 0,37^{a}$ & $13,95 \pm 0,11^{\mathrm{b}}$ & $10,82 \pm 0,10^{c}$ & $15,21 \pm 0,22^{b}$ & 0,000 \\
\hline \multirow{5}{*}{$\begin{array}{l}\text { Konsentrasi } \\
\text { RNA ( } \mu \mathrm{g} / \\
\text { mg) }\end{array}$} & 8 & $16,50 \pm 0,21^{\mathrm{a}}$ & $10,74 \pm 0,18^{\mathrm{b}}$ & $10,24 \pm 0,04^{\mathrm{c}}$ & $10,33 \pm 0,08^{\mathrm{c}}$ & 0,000 \\
\hline & 12 & $10,97 \pm 0,89$ & $10,15 \pm 0,06$ & $10,29 \pm 0,19$ & $10,22 \pm 0,11$ & 0,906 \\
\hline & 16 & $11,89 \pm 2,00$ & $10,14 \pm 0,24$ & $10,19 \pm 0,01$ & $10,35 \pm 0,30$ & 0,185 \\
\hline & 20 & $11,01 \pm 1,26^{a}$ & $10,03 \pm 0,33^{\mathrm{ab}}$ & $8,96 \pm 0,01^{b}$ & $10,34 \pm 0,25^{a}$ & 0,029 \\
\hline & 24 & $10,58 \pm 0,63$ & $10,04 \pm 0,14$ & $10,12 \pm 0,03$ & $10,16 \pm 0,21$ & 0,403 \\
\hline \multirow{8}{*}{$\begin{array}{l}\text { Rasio RNA/ } \\
\text { DNA }\end{array}$} & 32 & $10,84 \pm 0,81$ & $9,88 \pm 0,70$ & $10,08 \pm 0,03$ & $10,14 \pm 0,17$ & 0,313 \\
\hline & 4 & $1,993 \pm 0,05^{\mathrm{a}}$ & $1,684 \pm 0,01^{b}$ & $1,251 \pm 0,01^{\mathrm{c}}$ & $1,822 \pm 0,04^{\mathrm{b}}$ & 0,038 \\
\hline & 8 & $1,899 \pm 0,12^{\mathrm{a}}$ & $1,267 \pm 0,03^{b}$ & $1,254 \pm 0,01^{b}$ & $1,237 \pm 0,02^{\mathrm{b}}$ & 0,000 \\
\hline & 12 & $1,261 \pm 0,04^{\mathrm{ab}}$ & $1,206 \pm 0,02^{\mathrm{bc}}$ & $1,262 \pm 0,04^{a}$ & $1,118 \pm 0,01^{\mathrm{c}}$ & 0,038 \\
\hline & 16 & $1,446 \pm 0,22$ & $1,254 \pm 0,05$ & $1,272 \pm 0,01$ & $1,245 \pm 0,03$ & 0,182 \\
\hline & 20 & $1,118 \pm 0,18^{\mathrm{ab}}$ & $1,269 \pm 0,09^{a}$ & $1,107 \pm 0,01^{\mathrm{b}}$ & $1,255 \pm 0,04^{a}$ & 0,020 \\
\hline & 24 & $1,286 \pm 0,88^{a}$ & $1,223 \pm 0,03^{\mathrm{ab}}$ & $1,267 \pm 0,01^{\mathrm{ab}}$ & $1,177 \pm 0,04^{b}$ & 0,010 \\
\hline & 32 & $1,117 \pm 0,11$ & $1,285 \pm 0,17$ & $1,228 \pm 0,01$ & $1,243 \pm 0,02$ & 0,891 \\
\hline
\end{tabular}

Keterangan: (a-c) superscript huruf yang berbeda pada baris yang sama menunjukkan perbedaan nyata $(\mathrm{p}<0,05)$

Kadar insulin dalam jaringan otak anak tikus berbeda $(\mathrm{p}<0,05)$ antara anak tikus yang dilahirkan oleh tikus kontrol dan yang dilahirkan oleh induk tikus yang diberi asam valproat. Kadar insulin rata-rata pada kelompok anak tikus berturut-turut $27,27 \pm 6,06,14,45 \pm 5,23$; $12,63 \pm 4,31$, dan $14,90 \pm 5,2 \mu \mathrm{g} / \mathrm{g}$. Kadar insulin jaringan otak pada periode pertumbuhan minggu ke-4 hingga minggu ke-32 memperlihatkan perbedaan $(p<0,05)$, terlihat bahwa kadar insulin rata-rata yang tinggi pada minggu ke-4 dan kemudian mengalami penurunan pada minggu ke-32 (Gambar 2).

Konsentrasi DNA dalam jaringan otak yang didapatkan pada kelompok anak tikus yang dilahirkan oleh induk kontrol berbeda nyata $(p<0,01)$ dibanding dengan anak tikus yang dilahirkan oleh induk yang diberi asam valproat pada umur kebuntingan 10, 13, dan 16 hari dengan nilai berturut-turut sebesar $8,83 \pm 0,53$; $8,16 \pm 0,42 ; 8,18 \pm 0,18$; dan $8,39 \pm 0,21 \mu \mathrm{g} / \mathrm{mg}$. Konsentrasi RNA dalam jaringan otak tikus percobaan berbeda nyata $(\mathrm{p}<0,01)$; pada anak tikus dari induk kontrol dan anak tikus yang dilahirkan oleh induk yang diberi asam valproat pada umur kebuntingan 10,13 , dan 16 hari secara berturut-turut $12,88 \pm 0,88 ; 10,71 \pm 1,40$; $10,10 \pm 0,53$; dan 10,96 $\pm 1,78 \mu \mathrm{g} / \mathrm{mg}$. (Tabel 2).

Nilai rasio RNA/DNA rata-rata yang sudah didapatkan pada anak tikus yang dilahirkan oleh induk tikus kontrol $(1,46 \pm 0.34)$ secara signifikan lebih tinggi $(\mathrm{p}<0.05)$ bila dibanding dengan anak tikus yang dilahirkan oleh induk tikus yang diberi asam valproat pada umur kebuntingan 10, 13, dan 16 hari berturut-turut adalah $1,31 \pm 0,17 ; 1,23 \pm 0,05$; dan $1,31 \pm 0,21$. Konsentrasi DNA, RNA, serta rasio RNA/DNA pada periode pertumbuhan baik pada anak tikus 
Komariah: Pemberian Asam Valproat pada Induk Tikus Bunting Menghambat Sintesis Insulin pada Sel Otak Anak Tikus

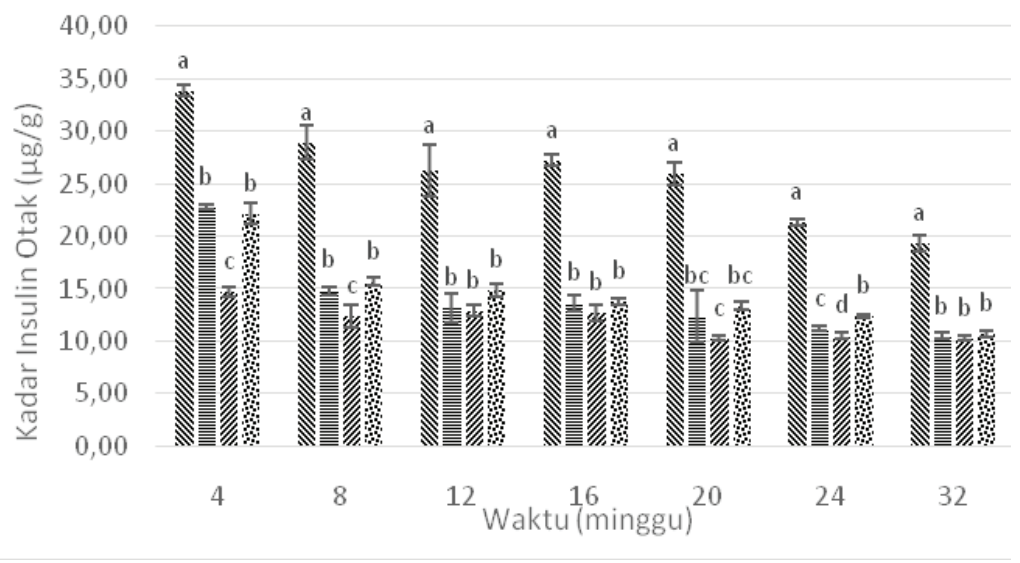

\section{Gambar 2 Kadar Insulin Otak Anak Tikus yang Dilahirkan oleh Kelompok Induk K0, Induk Tikus Kelompok K1, K2, dan Kelompok Induk K3}

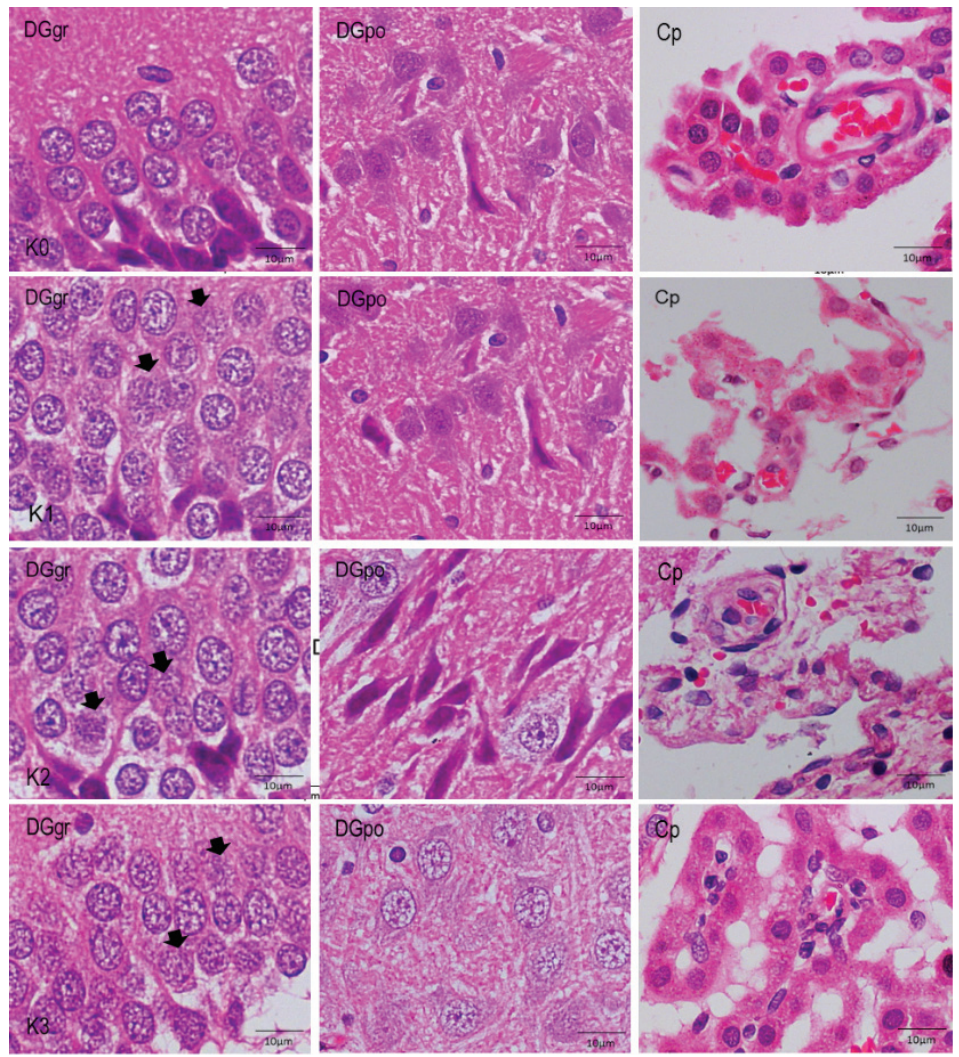

\section{Gambar 3 Gambaran Histomorfologis Dentate Gyrus Hipokampus dan Pleksus Koroid (HE)}

$\mathrm{K} 0=$ anak yang dilahirkan oleh induk kontrol; $\mathrm{K} 1=$ anak tikus yang dilahirkan oleh induk yang diberi asam valproat $250 \mathrm{mg}$ pada umur kebuntingan 10 hari; $\mathrm{K} 2=$ anak tikus yang dilahirkan oleh induk yang diberi asam valproat $250 \mathrm{mg}$ pada umur kebuntingan 13 hari; $\mathrm{K} 3=$ anak yang dilahirkan oleh induk yang diberi asam valproat $250 \mathrm{mg}$ pada umur kebuntingan 16 hari;DGpo=lapisan polimorf dentate gyrus, DGgr= lapisan granuler dentate gyrus, dan $\mathrm{Cp}=$ pleksus koroid, sel-sel yang mengalami degenerasi. 

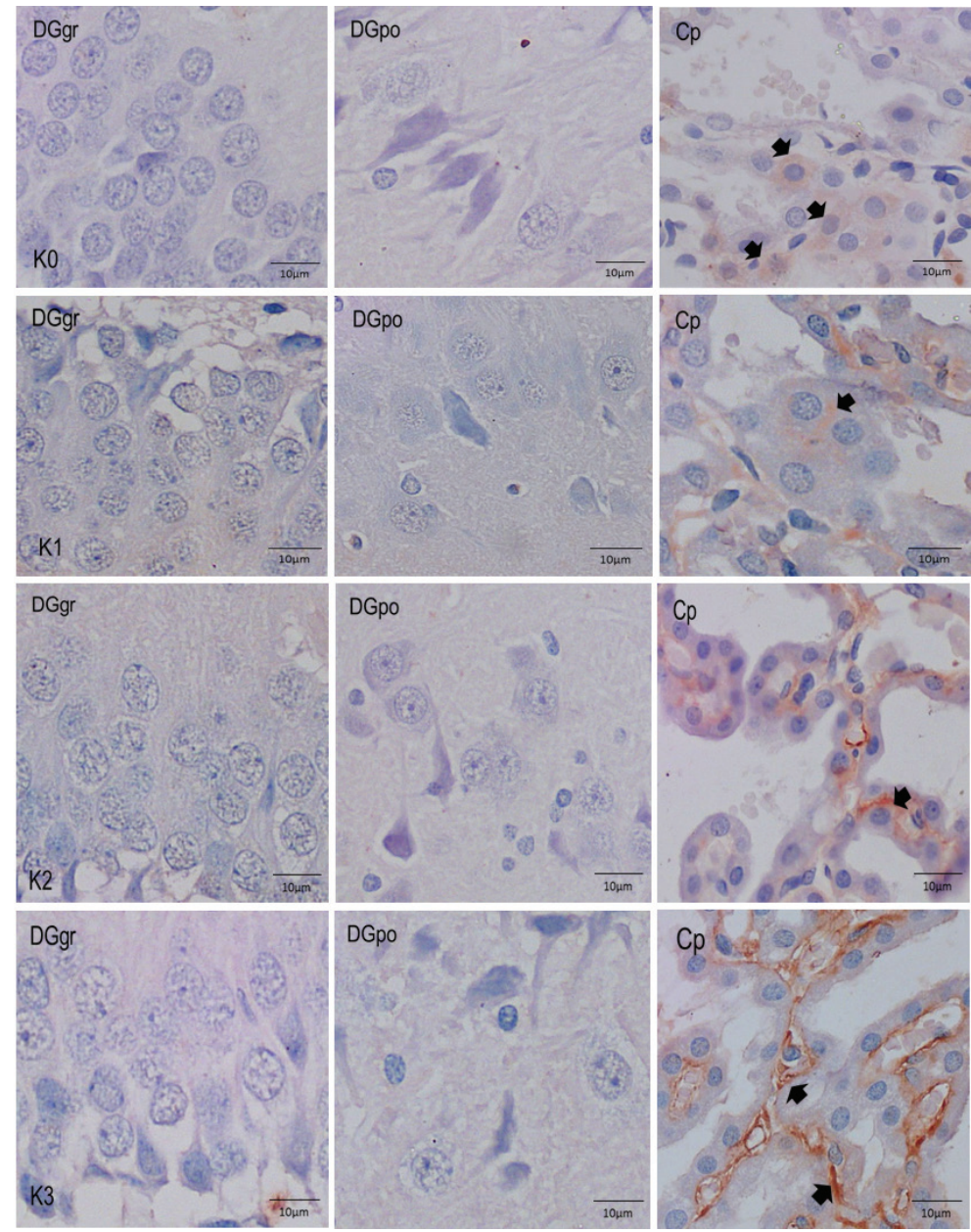

\section{Gambar 4 Gambaran Histopatologis Dentate Gyrus dan Pleksus Koroid (Imuonohistokimia dengan} Ab Anti Human Insulin)

K0 ialah kelompok anak tikus dari induk kontrol, K1, K2, dan K3 ialah kelompok anak tikus yang dilahirkan oleh induk yang diberi asam valproat 250 mg pada umur kebuntingan hari ke-10, 13, 16; DGpo=lapisan polimorf dentate gyrus, DGgr = lapisan granuler dentate gyrus, $\mathrm{Cp}=$ pleksus koroid, sel-sel pleksus koroid yang imunoreaktif terhadap insulin.

dari kelompok induk tikus kontrol dan induk tikus kelompok perlakuan asam valpoat pada umur kebuntingan 10, 13, dan 16 hari tidak berbeda nyata $(\mathrm{p}>0,05)$.

Pengamatan mikroskopis otak dilakukan dengan mengamati struktur sel yang terdapat pada DG hipokampus yang memperlihatkan lapisan polimorfdentate gyrus (DGpo) dan juga lapisan granuler dentate gyrus (DGgr), dengan pewarnaan HE sel-sel saraf terlihat mengalami proses degenerasi sel, khususnya pada lapisan granuler yang padat dengan sel-sel saraf (Gambar 3).

Pengamatan hasil pewarnaan imunohistokimia dilakukan pada potongan jaringan otak anak tikus pada semua kelompok pada sel-sel saraf di DG yang dapat memberikan imunoreaktif terhadap insulin. Tampak pada pengamatan mikroskopis sel-sel saraf di bagian DGpo dan DGgr tidak memperlihatkan terdapat sel-sel yang imunoreaktif terhadap insulin, baik pada kelompok anak tikus dari induk kontrol maupun kelompok anak tikus dari induk perlakuan, namun imunoreaktif insulin terjadi pada bagian pleksus koroid (Gambar 4).

\section{Pembahasan}

Penggunaan VPA selama kehamilan mampu menyebabkan malformasi kongenital. Hal ini disebabkan oleh 91-95\% VPA mampu berikatan 
dengan protein plasma, yang dapat ditransfer melalui plasenta, baik pada hewan maupun manusia. ${ }^{12}$ Proses organogenesis otak tikus terjadi berdasar perhitungan hari, sedangkan pada manusia perhitungan adalah dari minggu ke bulan. Meskipun demikian, perkembangan otak tikus dan manusia memiliki kemiripan. ${ }^{13}$

Kadar glukosa darah anak tikus yang tinggi pada kelompok induk tikus yang diberi asam valproat menunjukkan bahwa asam valproat memengaruhi proses organogenesis otak anak tikus dari induk yang diberi asam valproat. Perbedaan waktu peningkatan kadar glukosa otak pada kelompok anak tikus berkorelasi dengan peningkatan kadar glukosa darah. Menurut Nigrovicet dkk. ${ }^{14}$ peningkatan kadar glukosa darah diikuti dengan peningkatan kadar glukosa otak, begitu pula dengan penurunan kadar glukosa darah. Glukosa masuk ke dalam otak melalui kapiler sawar darah otak yang mengaktifkan GLUT1 dan GLUT 4 yang tidak responsif terhadap insulin sehingga otak bersifat independen terhadap insulin dalam penyerapan glukosa. ${ }^{15}$

Keberadaan insulin dalam otak pertama kali dideteksi mempergunakan radioimmunoassay. Kadar insulin otak memperlihatkan jumlah 10 kali atau 100 kali lebih tinggi dibanding dengan kadar insulin dalam sirkulasi. ${ }^{15}$ Meskipun kontrol homeostasis glukosa perifer merupakan salah satu fungsi utama insulin, aksi insulin pada otak sangat penting karena otak merupakan organ yang sensitif insulin. ${ }^{1}$ Dengan teridentifikasinya reseptor insulin (IR) dan jalur transduksi signal pada beberapa daerah di otak memungkinkan insulin memiliki peran fisiologi penting, seperti pada perkembangan sel neuron, glukoregulator, menekan perilaku makan, mengkontrol berat badan, proses kognitif, termasuk rasa perhatian, pembelajaran, dan memori. ${ }^{1}$

Menurut Blazquez dkk. ${ }^{1}$ insulin dalam otak bersifat independen yang tidak terpengaruh oleh kadar insulin dalam sirkulasi. Keberadaan insulin di otak dapat berasal dari sirkulasi yang melewati sawar darah otak melalui receptormediated transport atau karena kemampuan otak untuk mensintesis insulin. Sel-sel pada daerah DG hipokampus diduga telah menyekresi insulin yang digunakan untuk regenerasi sel-sel saraf. ${ }^{8}$ Menurut Kuwabara dkk. ${ }^{8}$ sel-sel saraf secara terus menerus memperbaharui diri di DG dan proses ini dipromotori oleh pelepasan Wnt3 dari sel glia astrosit. Pensignalan $W n t 3$ menginduksi ekspresi NeuroD1 (faktor transkripsi) yang berperan penting dalam perkembangan pankreas dan otak yang diperlukan untuk ekspresi gen insulin.
Kadar insulin dalam jaringan otak kelompok anak tikus dari induk kontrol tanpa pemberian asam valproat lebih tinggi dibanding dengan kelompok anak dari induk yang diberi asam valproat 250 mg pada umur kebuntingan 10, 13, dan 16 hari yang terjadi akibat gangguan proses organogenesis otak. Peningkatan kadar insulin otak tidak berkorelasi dengan peningkatan kadar insulin darah.

Paparan asam valproat yang memiliki sifat teratogenik tersebutbekerja dalam memengaruhi modifikasi histon dengan jalan menghambat aktivitas $\mathrm{HDAC}^{7}$ menyebabkan hiperasetilasi pada H4K16. ${ }^{16}$ Hiperasetilasi merupakan salah satu penyebab respons terhadap kerusakan DNA. ${ }^{17} \mathrm{Hal}$ ini diperlihatkan dengan konsentrasi DNA yang tinggi pada kelompok anak tikus yang dilahirkan oleh induk kontrol. Hasil analisis konsentrasi DNA kelompok anak tikus dari induk perlakuan menunjukkan gangguan pada siklus replikasi sel, termasuk replikasi DNA.

Konsentrasi RNA menunjukkan tinggi dan aktivitas sintesis protein yang secara genetik berlangsung pada sintesis RNA. Jika RNA disintesis itu secara aktif maka pertumbuhan sel berlangsung lebih cepat. Oleh karena itu, kecepatan pertumbuhan sel sangat terkaitdengan rasio konsentrasi RNA/DNA yang merupakan bentuk ekspresi karakter pertumbuhan sel dalam jaringan. ${ }^{18}$ Rasio RNA/DNA pada kelompok anak tikus yang dilahirkan oleh induk kontrol tanpa pemberian asam valproat lebih tinggi dibanding dengan anak yang dilahirkan oleh induk yang diberi asam valproat.

Pada gambaran mikroskopis DGpo dan juga DGgr dengan pewarnaan HE memperlihatkan perubahan morfologi sel-sel saraf dentate gyrus hipokampus. Hilangnya inti sel serta ukuran sel saraf menunjukkan degenerasi pada sel-sel saraf penghasil insulin. Untuk membuktikannya maka dilakukan perwarnaan imunohistokimia insulin. Hasil pewarnaan imunohistokimia pada jaringan otak tidak terdapat sel-sel yang imunoreaktif terhadap insulin pada daerah dentate gyrus, baik pada kelompok anak tikus yang dilahirkan oleh induk kontrol maupun kelompok anak yang dilahirkan oleh induk yang diberi asam valproat. Namun imunoreaktif terhadap insulin tampak terlihat pada sel-sel yang terdapat di pleksus koroid jaringan otak.

Menurut Gray dkk ${ }^{15}$ untuk dapat mendeteksi keberadaan insulin dengan imunoreaktif insulin tidak dapat membuktikan sumber sel penghasil insulin, diduga karena sintesis insulin yang rendah pada sel-sel saraf di dentate gyrus. Menurut Kuwabara $\mathrm{dkk}^{8}$ sel penghasil insulin 
terdeteksi pada lapisan granuler DG, lapisan CA1, dan lapisan CA3 hipokampus. Produksi insulin oleh sel-sel saraf akibat induksi gen Wnt3 yang disekresikan oleh sel glia astrosit dan gen Wnt3 tidak hanya disekresi oleh sel glia astrosit, namun juga oleh sel alfa pankreas. ${ }^{6}$

Pleksus koroid tersusun oleh sel-sel epitel pada membran basalis yang menghasilkan cairan serebrospinal (CSF) danInsulin-like growth factor 1 (IGF-1) yang bersifat imunoreaktif terhadap insulin. ${ }^{19}$ Tidak terdapat sel-sel dentate gyrus yang imunoreaktif terhadap insulin disebabkan oleh jumlah insulin yang disintetis terlalu rendah sehingga imunoreaktif terhadap insulin tidak terlihat dengan jelas.

Pemberian asam valproat pada induk tikus belum juga memperlihatkan gejala klinis pada anak tikus yang dilahirkan, namun dampak tersebut dapat terlihat secara mikroskopik terdapat degenerasi sel-sel saraf yang diikuti dengan penurunan konsentrasi DNA, RNA, dan ratio RNA/DNA. Meskipun RNA tidak spesifik insulin, namun hasil penelitian menunjukkan penurunan sekresi insulin otak anak tikus selama masa pertumbuhan. Hal ini memperlihatkan bahwa pemberian asam valproat selama masa kebuntingan tidak secara langsung memberikan gejala klinis pada anak tikus, namun kemampuan asam valproat dalam memengaruhimodifikasi histon selama proses organogenesis otak dapat memengaruhi perkembangan sel-sel saraf otak anak tikus.

Pemberian asam valproat pada induk tikus umur kebuntingan 10, 13, dan 16 hari memengaruhi organogenesis otak anak tikus, diperlihatkan pada pewarnaan HE yang terjadi perubahan morfologi menuju degenerasi dari sel-sel saraf, diikuti penurunan konsentrasi DNA, RNA, dan rasio RNA/DNA yang semakin jelas dengan pertambahan umur. Selain itu, pada pewarnaan imunohistokimia tidak terdapat selsel imunoreaktif terhadap antibodi anti human insulin pada daerah dentate gyrus.

\section{Daftar Pustaka}

1. Blázquez E, Velazquez E, Carneiro $\mathrm{CH}$, Albusac JMR. Insulin in the brain: its pathophysiological implications for states related with central insulin resistance, type 2 diabetes and alzheimer's disease. Front Endocrinol. 2014;161(5):161.

2. Desai M, Li T, Ross MG. Fetal hypothalamic neuroprogenitor cell culture: preferential differentiation paths induced by leptin and insulin. Endocrinology. 2011;152(8):3192201.

3. Ghafari S, Asadi E, Shabani R, Golalipour MJ. Hippocampal neuronal apoptosis in rat offspring due to gestational diabetes. Int J Morphol. 2016;34(1):205-11.

4. Kleinridders A, Ferris HA, Cai W, Ronald Kahn C. Insulin action in brain regulates systemic metabolism and brain function. Diabetes. 2014;63(7):2232-43.

5. Ximenes JCM,Verde ECL, Naffah-Mazzacoratti MG, Viana GSB.Valproic acid, a drug with multiple molecular targets related to its potential neuroprotective action. Neurosci Med. 2012;3:107-23.

6. Shahien R, Beiruti K. Preventive agents for migraine: focus on the antiepileptic drugs. J Cent Nerv Syst Dis. 2012;4:37-49.

7. Karen J, Rodriguez A, Friman T, Dencker D, Sundberg S, Scholz B. Effects of the histone deacetylase inhibitor valproic acidon human pericytes in vitro. Plos One. 2011;6(9):1-11.

8. Kuwabara T, Mohamedi NK, Onuma Y, Yuzuru I, Warashina M. Terashima K, dkk. Insulin biosynthesis in neuronal progenitors derived from adult hippocampus and the olfactory bulb. EMBO Mol Med. 2011;3(12):742-54

9. Schwartz MW, Guyenet SJ, Cirulli V. The hypothalamus and beta-cell connection in the gene-targeting era. Diabetes. 2010;59(12):2991-3.

10. Sanchez AM, Rutter GA, Latreille M. MiRNAs in $\beta$-cell development, identity, and disease. Front Genet. 2017;7(266):1-19.

11. Dahlan MS. Statistik untuk kedokteran dan kesehatan: deskriptif, bvariat, dan multivariant. Jakarta: Epidemiologi Indonesia; 2014.

12. Aluclu MU, Tuncer MC, Guzel A, Aluclu MA, Akkus M. The effects of valproic acid on sciatic nerve of fetal rats and protective effects of folic acid and vitamin E. Int J Morphol. 2009;27(2):285-94.

13. Clancy B, Finlay BL, Darlington RB, Anand KJS. Extrapolating brain development from experimental species to humans. Neurotoxicology. 2007;28(5):1-7.

14. Nigrovic LE, Kimia AA, Shah SS, Neuman MI. Relationship between cerebrospinal fluid glucose and serum glucose. $N$ Engl J Med. 2012;366 (6):576-8.

15. Gray SM, Meijer RI, Barrett EJ. Insulin regulates brain function, but how does it get there?. Diabetes. 2014;63(12):3992-7.

16. Giavini E, Menegola E. Teratogenic activity of HDAC inhibitors. Curr Pharm. 2014;20:1-6. 
17. Rajendran $\mathrm{P}$, Kidane AI, Yu TW, Dashwood WM, Bisson WH, Löhr CV, Ho E, dkk. HDAC turnover, CtIP acetylation and dysregulated DNA damage signaling in colon cancer cells treated with sulforaphane and related dietary isothiocyanates. Epigenetics. 2013;8(6): 612-23.

18. Parenrengi A, Tonnek S, Tenriulo A. Analisis rasio RNA/DNA udang windu Penaeus monodon hasil seleksi tumbuh cepat. J Ris Akuakultur. 2013;8(1):1-12.

19. Nishijima T, Piriz J, Duflot $S$, Fernandez AM, Gaitan G, Pinedo UG, dkk. Neuronal activity drives localizedblood-brainbarrier transportof serum insulin-like growth factor-i into the CNS. Neuron. 2010;67(5):834-46. 